\title{
Procjena postmortalnog intervala na temelju postmortalnih promjena i entomološkog nalaza
}

\author{
M. Palić, L. Šerić Jelaska, P. Džaja, A. Gudan Kurilj i K. Severin*
}

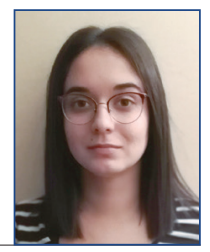

\section{Sažetak}

Postmortalnim intervalom (PMI) nazivamo vrijeme koje je proteklo od trenutka uginuća životinje. Njegovom procjenom dolazimo do spoznaja vezanih uz način i okolnosti smrti, a u pojedinim slučajevima pomaže nam u pronalaženju počinitelja. U ovom radu prikazan je slučaj u kojemu je postavljena sumnja da je došlo do počinjenja kaznenog djela ubijanja i mučenja životinje te je osim uzroka uginuća bilo potrebno ustvrditi postmortalni interval. Određivanje PMI-a se temeljilo na procjeni postmortalnih promjena i entomološkog nalaza. Nakon smrti, životinjsko tijelo prolazi kroz određene promjene koje su posljedica prestanka životnih funkcija i smrti stanica. Nastale promjene su nepovratne $\mathrm{i}$ progresivne te $\mathrm{u}$ konačnici dovode do potpunog raspadanja tijela. Tijekom razudbe ustvrđeni su uznapredovali znaci truljenja i izostanak mrtvačke ukočenosti te je bilo nemoguće precizno ustvrditi PMI isključivo na temelju postmortalnih promjena. U ovakvim ili sličnim slučajevima gdje postoji postmortalna kolonizacija kukcima moguće je ustvrditi PMI određivanjem vrste i starosti razvojnih stadija te utjecaja okolišnih faktora na njihov razvoj. Prema dostupnim entomološkim dokazima na temelju uočenih morfoloških obilježja ustvrđeno je da se radi o ličinkama iz porodice muha zujara (Calliphoridae) te se s određenom razinom sigurnosti pretpostavilo da je riječ o vrsti Calliphor vicina. Naime, zbog propusta pri prikupljanju i pohrani uzoraka nije bilo moguće na temelju morfološke razudbe i molekularnim analizama ustvrditi točan identitet vrste. Unatoč tome, entomološki nalaz je bitno doprinio u procjeni PMI i na taj način pomogao u rješavanju slučaja.

Ključne riječi: postmortalni interval, postmortalne promjene, forenzička entomologija, pas

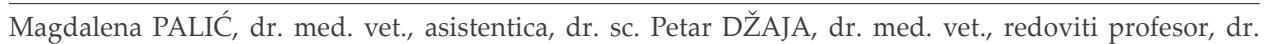
sc. Andrea GUDAN KURILJ, dr. med. vet., izvanredna profesorica, dr. sc. Krešimir SEVERIN*, dr. med. vet., redoviti profesor, (dopisni autor, e-mail: severin@vef.hr), Veterinarski fakultet Sveučilišta u Zagrebu, Hrvatska; dr. sc. Lucija ŠERIĆ JELASKA, stručna savjetnica, viša znanstvena suradnica, Biološki odsjek, Prirodoslovno-matematički fakultet Sveučilišta u Zagrebu, Hrvatska 


\section{Uvod}

Neizostavni dio pri razudbi lešina je prosuđivanje postmortalnog intervala (PMI), odnosno vremena koje je proteklo od uginuća životinje do pronalaska, odnosno trenutka razudbe lešine tijekom koje se ustvrđuju postmortalne promjene. Ona je posebice bitna $u$ slučajevima neprirodne i sumnjive smrti (Aydin i sur., 2010.). Osim toga, može nam pomoći u pronalaženju počinitelja te katkada ukazati na okolnosti u kojoj je smrt nastupila (Munro i Munro, 2008.). Postoje tri načina ustvrđivanja PMI-a s obzirom na dokaz: anamnestički dokaz (na temelju navika, kretanja i aktivnosti životinje), okoliš i s okolišem povezani dokaz (prisutan u blizini tijela) i fizički dokaz (prisutan u tijelu). Svi ovi načini uz izjave svjedoka ili istražni nalaz, uključuju i kada je životinja posljednji put viđena živa, treba uzeti u obzir prije formiranja mišljenja o trenutku smrti ili ozljede (Merck i Miller, 2013.). Drugim riječima, precizno ustvrđivanje uključuje razmatranje brojnih čimbenika, od utjecaja okoliša do fizičkih i biokemijskih promjena koje se u tijelu nakon smrti događaju. Nakon smrti životinje uslijed prestanka cirkulacije dolazi do razvoja postmortalnih promjena koje često $u$ literaturi nazivaju sigurnim znacima smrti (signa mortis) (Grabarević i Sabočanec, 2016.). Promjene koje nastaju nepovratne su i progresivne, pojavljuju se i nestaju određenim redoslijedom (Brooks, 2016.). Neizostavni dio pri prosuđivanju PMI-a je analiza navedenih promjena koje dijelimo na rane i kasne, odnosno na vjerojatne i sigurne znakove smrti. U rane znakove smrti ubrajamo mrtvačku hladnoću (algor mortis), mrtvačke pjege (livore mortis) te mrtvačku ukočenost (rigor mortis) (Škavić, 2004.). U trenutku smrti zaustavljaju se procesi stanične aktivnosti i oksidacije, dok se zaostala tjelesna toplina istovremeno odaje u okoliš pri čemu dolazi do hlađenja lešine (algor mortis) (Brooks, 2016.). Za očekivati je da se tijelo (objekt) hladi po Newtonovom zakonu, koji kaže kako je brzina hlađenja razmjerna razlici između temperature površine tijela i okoliša (Škavić, 2004.). Međutim, ovaj zakon ne vrijedi za biološku materiju kao što je lešina. Poznato je da nakon smrti temperatura tijela $u$ pasa pada za 0,5 na sat (Proctor, 2009.). Pojedini autori navode kako pad temperature u unutrašnjosti ne prati pad temperature na površini tijela što se pripisuju aerobnom i anaerobnom postmortalnom metabolizmu ili bakterijskim metaboličkim procesima u crijevima (Brooks, 2016.). Mjerenjem rektalne temperature moguće je odrediti približno vrijeme smrti unutar prvih 10 sati. Nakon ovog vremenskog perioda dolazi do postupnog izjednačavanja temperature tijela s okolišnom temperaturom. U istraživanju koje su proveli Erlandsson i Munro (2007.) temperatura promatranih lešina pasa dosegnula je okolišnu temperaturu za 24 do 48 sati nakon smrti.

Prestankom rada srca i zaustavljanjem cirkulacije, unutar 30 minuta do 2 sata dolazi do slijeganja nezgrušane krvi (hypostasis sanguinis postmortalis) (Brooks, 2016.). Pod utjecajem gravitacijske sile nezgrušana krv se slijeva u niže dijelove tijela (Džaja i Grabarević, 2011.). $\mathrm{Na}$ strani slijeganja, javlja se ljubičasto prebojavanje kože i sluznica te organa u trbušnoj ili prsnoj šupljini što nazivamo mrtvačkim pjegama (livores mortis), dok se na suprotnoj strani lešine javlja mrtvačko bljedilo (pallor mortis). U životinja zbog dlačnog pokrivača najuočljivije je na potkožju, očnim spojnicama te parnim parenhimatoznim organima ponajprije plućima (Grabarević i Sabočanec, 2016.). Smatra se kako je livor mortis u prvih 8 do 12 sati nefiksiran jer pritiskom na mrtvačke pjege one blijede što $u$ tom stadiju treba razlikovati od krvarenja. No, istekom 
toga vremena prebojenje kože postaje fiksirano te ga je pritiskom nemoguće ukloniti (Brooks, 2016.). Obično dijelovi lešine prislonjeni na čvrstu podlogu ostaju obezbojeni zbog pritiska na krvne žile što se naziva kontaktnim mrtvačkim bljedilom. Upravo ova činjenica može odgovoriti na pitanje je li tijelo pomicano s mjesta zločina (Merck i Miller, 2013.). Najizrazitija promjena koju zapažamo na lešini je mrtvačka ukočenost (rigor mortis) (Grabarević i Sabočanec, 2016.). U trenutku smrti u mišićnim vlaknima dolazi do prestanka stvaranja adenozin trifosfata (ATP), dok ujedno dolazi i do njegove razgradnje. Upravo zbog toga uslijed manjka energije koja je potrebna za proces relaksacije, mišićna vlakna ostaju u grču (Škavić, 2004.). Obično započinje 2 do 6 sati (prosječno 2-4 sata) nakon smrti i traje 36 sati nakon čega počinje popuštati. Međutim, treba naglasiti kako je mrtvačka ukočenost pod izrazitim utjecajem okolišne temperature te uvelike ovisi o uzroku uginuća (Brooks, 2016.). U iscrpljenih životinja dolazi do njezina trenutnog nastajanja (kataleptička ukočenost), bez prethodne faze mrtvačke mlohavosti zbog potrošnje ATP-a (Merck i Milller, 2013.). Mišićje se obično koči određenim redoslijedom te se prvo koče mišići koji su zaživotno bili aktivniji. Ovakav redoslijed predstavlja Nystenov redoslijed kočenja ili descendentni tip kočenja (typus descendens). Obrnuti redoslijed kočenja, pri kojemu se prvo koče mišići stražnjih ekstremiteta karakterističan je za zeca i zove se ascendentni tip kočenja (typus ascendens) (Grabarević i Sabočanec, 2016.). Mrtvačka ukočenost obično traje sve do trenutka fizičkog pomicanja tijela, kada prestaje, no nakon nekog vremena se ponovno uspostavlja u različitom obujmu ovisno kada je prekinuta, u početku ili pri kraju nastajanja (Škavić, 2004.).

Istodobno navedenim promjenama lešina se postupno razgrađuje (decompositio), što uključuje proces autolize i truljenja (Merck i Miller, 2013.). Neposredno nakon smrti započinje proces samorazgradnje tijela, tj. autolize putem vlastitih enzima (autolysis). Ovaj proces rezultat je nedostatka kisika, uslijed čega stanice ne mogu održavati gradijent iona i integritet stanične membrane što dovodi do izlaženja citosolnih staničnih proteina u međustanični prostor (Brooks, 2016.). Autoliza je lančana reakcija koja određenim redoslijedom zahvaća tijelo i organe (Džaja i Grabarević, 2011.) te se obično prvo javlja na organima koji su bogati enzimima, kao što su gušterača i jetra. Meka tkiva poput: srca, krvnih žila, ligamenata, maternice i prostate pokazuju veću otpornost, dok kosti, hrskavice, dlaka i nokti ostaju najduže očuvani (Škavić, 2004.). Svojim napredovanjem autoliza vrlo brzo ustupa mjesto heterolizi (Brooks, 2016.), koja je obilježena izlaskom bakterija iz probavnog sustava i njihovim širenjem po organizmu što obično nazivamo truljenjem lešine (putrefactio) (Merck i Miller, 2013.). Truljenjem lešine dolazi do tipičnih promjena. Kao prvi znak truljenja javlja se prljavozeleno prebojavanje (pseudomelanosis) kože koje je obično izraženo na ventralnoj strani abdomena, te se javlja 24 sata nakon smrti (Munro i Munro, 2008.). Pojava prljavozelenog pigmenta posljedica je spajanja hemoglobina sa sumporovodikom nastalim tijekom truležnih procesa $u$ crijevima (Skavić, 2004.). Treba naglasiti kako je pseudomelanoza slabije izražena $\mathrm{u}$ pothranjenih i dehidriranih životinja zbog manjka crijevnoga sadržaja i slabije aktivnosti bakterija u crijevima (Munro i Munro, 2008.). Kako truležni procesi napreduju dolazi do nakupljanja truležnih plinova (vodik, amonijak, metan, ugljikov dioksid i drugi) koji dovode do nadutosti lešine (emphysema putrefactionis s. cadavericum) te stvaraju pritom truležni zadah (foetor putrefactionis) (Džaja i Grabarević, 2011.). U ljudi se nadutost lešine obično javlja u periodu od 60- 
72 sata nakon smrti. Prekid integriteta kože, njezino skidanje te gubitak dlačnog pokrivača je pojava koja je često vidljiva na lešinama, a posljedica je razgradnje tijela. Utjecaj putrefakcije, aktivnosti insekata i strvina $u$ konačnici dovodi do skeletonizacije lešine (Brooks, 2016.). Sve navedene promjene pod izrazitim su utjecajem intrinzičnih i ekstrinzičnih faktora, što treba imati u vidu prilikom procjene postmortalnog intervala. Osim procjene PMI-a na temelju postmortalnih promjena $\mathrm{u}$ današanje vrijeme sve je učestalija uporaba drugih metoda za koje je dokazana velika pouzdanost.

\section{"Who saw him die?" \\ "I," said the fly \\ "With my little eye, \\ I saw him die." \\ Greg Brown}

Jedna od najčešće korištenih metoda za procjenu minimalnog postmortalnog intervala (PMI min) je analiza kukaca koji se nalaze na lešinama $u$ različitim fazama raspadanja i njihovih razvojnih stadija (Anderson, 2013.). Ova je metoda naročito pouzdana ako je od smrti prošlo 72 sata (Defilipo i sur., 2016.). Uporaba kukaca intezivirana je početkom prošloga stoljeća te je došlo do razvoja nove discipline koja se naziva forenzička entomologija (Brundage i Byrd, 2016.). Kukci bivaju privučeni hlapljivim tvarima koje nastaju kao posljedica raspadanja tijela (apeneumoni). Prepostavlja se kako svaka faza raspadanja tijela dovodi do ishlapljivanja točnoodređenih spojevakoji utječu na ponašanje kukaca, a induciraju i ovipoziciju (Joseph i sur., 2011.). Među prvim kukcima koji koloniziraju lešina su vrste porodice muha zujara (Calliphoridae) čiji su najčešći predstavnici Chrysomya albiceps i Caliphorae vicinae (Salimi i sur., 2018.). Kolonizacija vrste započinje obično nekoliko minuta do nekoliko sati nakon smrti životinje (Pellitero i Bordas, 2007.). Ženka polaže jajašca najčešće oko prirodnih otvora, koja u razdoblju od 8-14 sati prelaze u stadij ličinke I. stupnja. Nakon idućih 8-14 sati ličinka I. stupnja prelazi u stadiji ličinke II. stupnja. Iduća 2 do 3 dana ona se hrani na lešini nakon čega prelazi u stadij ličinke III. stupnja koja se idućih 6 dana hrani kako bi se začahurila. Da bi se iz stadija kukuljice razvila odrasla jedinka potrebno je oko 12 dana. Dakle, možemo reći kako kompletan razvoj od jajašca do odrasle jedinke u prosjeku traje oko 18 do 24 dana ovisno o vrsti i utjecaju okoliša (Brooks, 2016.). C. vicina veliki udio životnog ciklusa provodi u stadiju ličinke, $50 \%$ u stadiju kukuljice (Brown i sur., 2015.), a svega $5 \%$ u stadiju jajašca (MartinVega i Hall, 2016.). Upravo iz tog razloga morfologija ličinaka je najistraženija (Brown i sur., 2014.) te se smatra najznačajnijim entomološkim dokazom. Prilikom prikupljanja entomoloških dokaza ličinke treba pravilno pohraniti, kako bi se izbjegla degradacija i druge postmortalne promjene koje bi mogle dovesti do pogrešaka u procjeni njihove morfologije i starosti (Džaja i Grabarević, 2011.). Najbolje ih je prikupiti na mjestu pronalaska lešine te zabilježiti mjesto $\mathrm{i}$ točne koordinate na kojem je lešina pronađena, kako bi se mogli prikupiti meteorološki podatci (Brundage i Byrd, 2016.). Prilikom uzorkovanja ličinaka, postoji protokol koji je razvila Europska udruga za forenzičku entomologiju (EAFE) koja preporučuje usmrćivanje i fiksiranje ličinaka uranjanjem u vruću vodu prije skladištenja u $80 \%$-tnom etanolu. Ovakvim se postupkom izbjegava raspadanje tkiva te promjena $u$ dužini ličinaka. Međutim, za usmrćivanje i fiskiranje jajašaca zbog njihove velike otpornosti preporučuje se stavljanje živih uzoraka izravno u 70-95 \%-tni etanol (Martin-Vega i Hall, 2016.). Prilikom prikupljanja uzoraka treba odvojiti ličinke iz kojih će se pokušati ustvrditi razvojni stadij, dok se dio ličinki može koristi u laboratoriju za razvoj do odraslog stadija 
pomoću koje bi se odredila vrsta (Byrd i Tomberlin, 2009.).

Razvojem molekularnih metoda, određivanje vrsta moguće je analizom DNK što se sve češće koristi unutar forenzičke entomologije (Moore i Shemilt, 2017.). Metoda određivanja genske ekspresije i količine steroidnih hormona potrebnih za proces presvlačenja i metamorfoze može se koristiti u ustvrđivanju starosti jedinke. Tijekom životnog ciklusa kukaca geni se u određenim fazama razvoja „uključuju i isključuju“, stvarajući na taj način proteine različite strukture i funkcije. Stoga je u pojedinim fazama njihova razvoja moguće izmjeriti razinu transkripcije određenih gena (Harvey i sur., 2016.). Temeljem ove metode provedena je studija na jajašcima vrste Lucilia sericata, gdje se pomoću ekspresije triju gena (BCD, SLL i CS) procjenjuje starost $u$ periodu od 2 sata (Sharmaa i sur., 2015.). Također, na temelju kemijskog profila kutikule (hitinska ovojnica koja služi kao zaštita) dobivenog plinskom kromatografijom može se odrediti vrsta i starost jedinke. Voštana kutikula je individualna za svaku vrstu te svaka vrsta kukca ima njezin jedinstveni kemijski profil što se poistovjećuje s otiskom prsta u ljudi (Moore i Shemilt, 2017.).

\section{Prikaz slučaja}

Prema zahtjevu jednog općinskog državnog odvjetinštva bilo je potrebno ustvrditi uzrok uginuća i starost lešine pronađene na mjestu na kojem se sumnja da je došlo do počinjenja kaznenog djela ubijanja i mučenja životinje. Dostavljena je lešina psa koja je pronađena u pvc vreći u prostoru napuštene štale. Prilikom pronalaska lešine 14-tog veljače, ista je pohranjena na $-20{ }^{\circ} \mathrm{C}$ čime je prekinuti razvoj postmortalnih procesa. Po dostavi lešina je slijedećeg dana pohranjena na $+4{ }^{\circ} \mathrm{C}$ do trenutka razdube. Potpunom razudbom lešine uspostavilo se kako se nalazi $u$ uznapredovalom stadiju postmortalnog raspadanja. Vanjskim pregledom uz odsustvo mrtvačke ukočenosti uočeni su uznapredovali znaci truljenja lešine poput stvaranja truležnih plinova (intenzivan osjet lešinskog zadaha, izbočena trbušna stjenka), prljavo zelenkasta prebojenja mjesta na koži trbuha (pseudomelanoza) te autolitično-truležni procesi koji se krakteriziraju krpičastim raspadanjem tkiva (dlaka i koža su vlažne i dlaka se lako skida prstima $s$ kože dok se na mekušima i njušci epidermis spontano odvaja od dermisa) (Slika 1.). Nedostatak kože na prednjoj lijevoj nozi u području podlaktice gdje se jasno uočavaju strukture potkožnih tkiva mišića, tetive i kosti, potkrepljuju tvrdnju o razvoju uznapredovalih procesa truljenja. Navedena promjena djelomično je ustanovljena na drugim udovima no u manjem intenzitetu. Stupanj truljenja lešine odgovara nalazu nakon skidanja kože i otvaranja tjelesnih šupljina. Pritom smo ustanovili ispunjenost crijeva i želudca velikom količinom plina (postmortalni meteorizam) uz izraženu pseudomelanozu organa trbušne šupljine

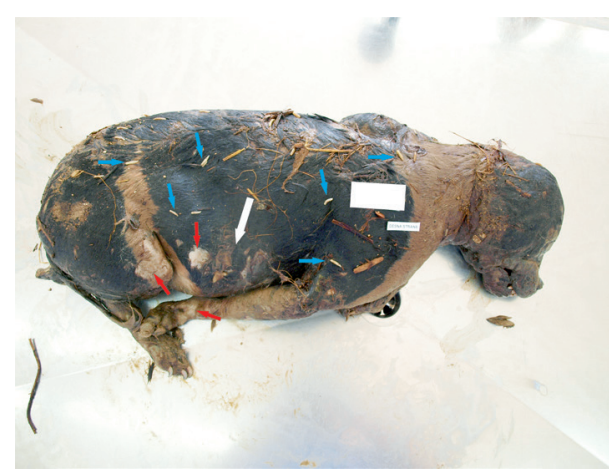

Slika 1. Lešina psa na kojoj se uočavaju uznapredovali znaci truljenja poput stvaranja truležnih plinova lizbočena trbušna stijenka, označeno bijelom strelicom) te autolitično truležni procesi vidljivi kao krpičasto raspadanje tkiva u vidu odvanja epidermisa od dermisa loznačeno crvenim strelicama). Na lešini je vidljiva larvalna kolonizacija (označeno plavim strelicama). 


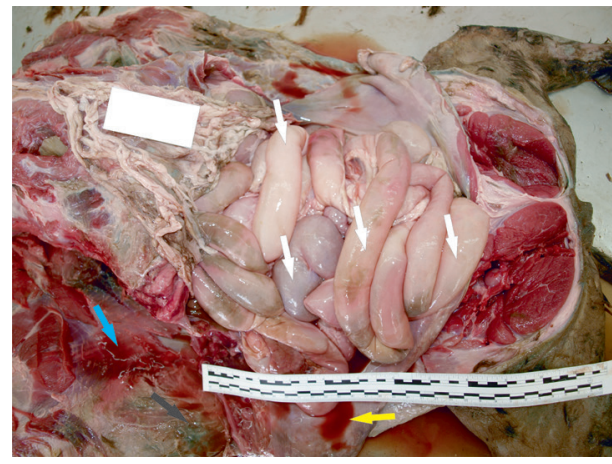

Slika 2. Otvorena abdominalna šupljina s vidljivim postmortalnim nadmom crijeva loznačeno bijelim strelicama), pseudomelanozom loznačeno crnom strelicom), krvnom imbibicijom (označeno plavom strelicom) i postmortalnim transudatom (označeno žutom strelicom).

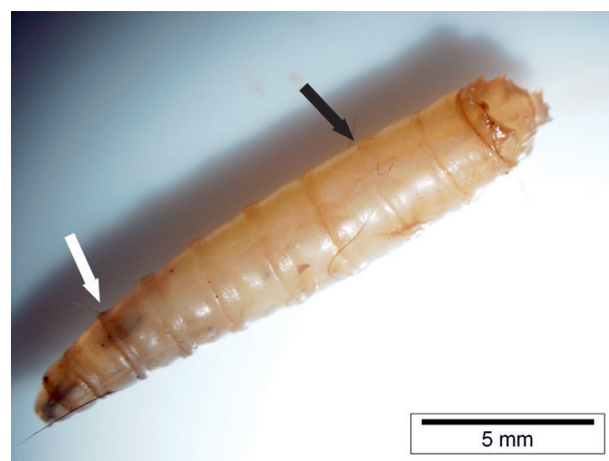

Slika 3. Ličinka muhe zujare (Calliphoridae) u trećem razvojnom stadiju. $U$ začanim (abdominalnim) segmentima nisu vidljive izbočine (označeno crnom strelicom). Na prsnom segmentu bijelom strelicom označeni trnovi posloženi u redovima.

koji imaju spužvasti izgled (kadaverozni emfizem) te nakupljanje crvene tekućine (postmortalnog transudata) u prsnoj šupljini kao posljedicu truljenja (Slika 2.).

Osim postmortalnih promjena na lešini je pronađeno oko tridesetak ličinaka čija se pojava povezuje s njezinim raspadanjem. Tri jedinke su fotografirane digitalnom kamerom (Olympus DP12) spojenom na stereomikroskop (Olympus SZX7) i predstavljaju jedini izvor za

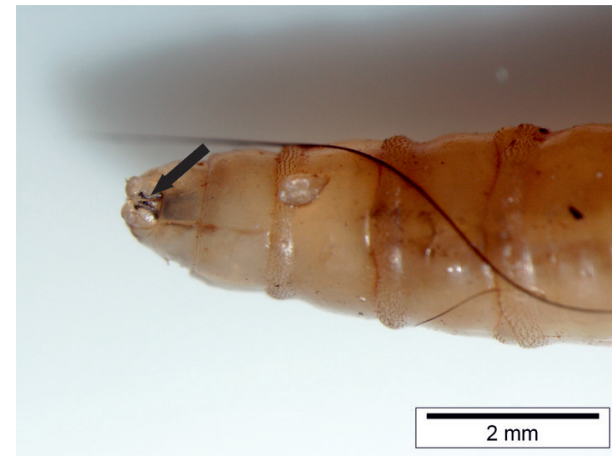

Slika 4. Ličinka muhe zujare (Calliphoridae) u trećem razvojnom stadiju. Crnom je strelicom označen oralni sklerit koji je cijelom svojom duljinom skeletoniziran.

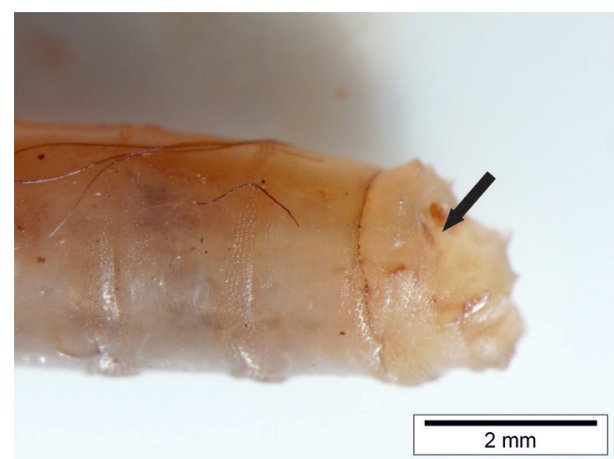

Slika 5. Ličinka muhe zujare (Calliphoridae) u trećem razvojnom stadiju. Crnom je strelicom označen položaj stražnjih odušaka. Broj otvora u odušcima odgovara trećem ličinačkom stadiju, a razmak između odušaka ne čini se duljim od promjera jednog oduška (zbog položaja odušaka na fotografiji, duljinu razmaka između odušaka nije bilo moguće izmjeriti).

identifikaciju. Prema obliku tijela i analne ploče ustvrđeno je da se radi o ličinkama iz porodice muha zujara (Calliphoridae). Opis ličinki u trećem razvojnom stadiju prema dostavljenim fotografijama: začani (abdominalni) segmenti bez istaknutih izbočina, oralni sklerit je sklerotiziran cijelom duljinom, trnovi na prsnim segmentima posloženi u redovima, stražnji odušci međusobno postavljeni bliže (položaj stražnjih odušaka nije 
adekvatno fotografiran te se ne može izmjeriti njihova međusobna udaljenost); također iz zaprimljenih fotografija nije razvidno jesu li 5, 6 i 7 ili samo 6 i 7 prstenovi na zatku djelomično prekriveni trnovima stoga se sigurna identifikacija preko fotografija može obaviti samo do roda (Slika 3.). Oblik cefaloskeletona i prednjih odušaka nije jasno vidljiv, trnovi na trećem prsnom segment također nisu vidljivi pri korištenom povećanju (Slika 4.) dok stražnji odušci na analnoj ploči oblikom sliče odušcima u vrste $C$. vicina (Slika 5.).

\section{Rasprava}

U prikazanom slučaju procjena postmortalnog intervala temeljila se na procjeni postmortalnih promjena i entomološkog nalaza. Razudbom lešine ustanovljeni su uznapredovali truležni procesi te izostanak mrtvačke ukočenosti. Kao što je već spomenuto raspadanje lešine započinje autolizom, dok se za 6 do 36 sati na nju nadovezuju truležni procesi (Merck i Miller, 2013.). Proces razgradnje tijela podijeljen je $u$ pet faza. Izostanak diskoloracija te aktivnosti kukaca na lešini može upućivati na postmortalni period od 0 do 5 dana. Obično kada nalazimo vidljive znakove truljenja poput pseudomelanoze, krvne imbibicije, pucanja stjenke organa zbog postmortalne nadutosti, gubitka dlačnog pokrova te kada se na pojedinim mjestima koža počinje skidati možemo reći kako je prošlo od 1-21 dan. Napredovanjem autolitčko-truležnih procesa dolazi do vlažnog (mokrog) raspadanja tkiva, ulegnuća (popuštanja konzistencije) mišića te izdubljivanja (kolabiranja) abdomena. Uz pojačanu aktivnost kukaca postupno dolazi do mumifikacije i/ili početka skeletonizacije što se događa u periodu između 3 dana do 18 mjeseci. Nalazi kostiju uz prisutsvo nešto tjelesnih tekućina ili tkiva koja pokriva manje od polovice skeletona obično upućuju na starost lešine od 13 dana do 3 godine. Smatra se kako za 2 mjeseca do 3 godine dolazi do ekstremnog raspada lešine, skeletonizacije $s$ izbjeljivanjem ili ljuštenjem (izuvanjem) ili gubitkom metafiza ili izlaganjem spužvaste kosti (Brooks, 2016.). Treba naglasiti da napredovanje truležnih procesa ovisi o čitavom nizu unutarnjih i vanjskih čimbenika. Prema Casparovom pravilu, stupanj truljenja uvelike ovisi o mediju u kojem se lešina nalazi. Lešina ostavljen na zraku četiri puta brže podliježe procesima truljenja nego u vodi, a dva puta brže od lešine zakopanog u zemlji. No, možemo reći kako je jedan od najvažnijih vanjskih čimbenika koji utječe na truljenje optimalna temperatura okoliša od 25 do $30{ }^{\circ} \mathrm{C}$ uz osrednju vlažnost zraka. Pri temperaturi ispod $5{ }^{\circ} \mathrm{C}$ i iznad $40{ }^{\circ} \mathrm{C}$ proces truljenja je znatno usporen, a može se inhibirati (Škavić, 2004.). Zamrzavanje pa odmrzavanje lešine dovodi do ubrzanja truležnih procesa te stvaranja mogućih artefakata. Lešine koji su bili zamrznuti prije obdukcije često pokazuju generalizirano prebojenje sluznice usta, potkožnog tkiva, mišića, leđne moždine, serozne površine crijeva, trbušne stijenke te sluznice traheje.

Ovakve artefakte treba razlikovati od aktivne ili pasivne hiperemije, hipostaze te pojedinih intoksikacija (Munro i Munro, 2008.). Kako bi smo odredili postmortalni interval na temelju ustvrđenih promjena, bilo je nužno ustvrditi temperaturu okoliša na mjestu nalaza lešine. U konkretnom slučaju, s ciljem ustvrđivanja temperature okoliša na mjestu nalaza lešine uzeli smo $u$ obzir uvjete u kojima je ona zatečena te kretanje prosječnih maksimalnih i minimalnih temperatura $s$ područja tijekom prethodnih desetak dana. Prema jedino dostupnim podatcima vidljivo je kako se temperatura od 3 . do 12 . veljače kretala od -3 do $9{ }^{\circ} \mathrm{C}$, dok je od 29. siječnja do 2 . veljače bila razmjerno viša i to od -3 do $16{ }^{\circ} \mathrm{C}$. Izostanak mrtvačke ukočenosti 
može se pripisati brojnim uzrocima i ne može nam dati precizan uvid kada je smrt nastupila. Smrzavanje tijela i niske temperature okoliša mogle su zaustaviti nastanak mrtvačke ukočenosti te se taj isti proces nakon odmrzavanja mogao nastaviti. U istraživanju koje su proveli Erlandson i Munro (2007.) u pasa koji su bili pohranjeni na temperaturi od 11 do $17{ }^{\circ} \mathrm{C}$, difuzna mrtvačka ukočenost nastupila je za manje od jednog dana, dok je njezina prisutnost na stražnjim udovima i čeljusti trajala do 7 dana. Treba uzeti u obzir kako i moguća manipulacija lešinom može dovesti do izostanka mrtvačke ukočenosti (Merck i Miller, 2013.). Prema svemu sudeći možemo procijeniti da je lešina $s$ obzirom na postmortalne promjene stara najmanje 72 sata, a najviše 2-3 mjeseca.

Tijekom razudbe na glavi lešine pronađeno je oko tridesetak ličinaka muha (Insecta: Diptera), što predstavlja relativno nisku postmortalnu infestaciju. Prosječna duljina ličinki iznosila je od 9 do $16 \mathrm{~mm}$. Uzorci su neposredno nakon razudbe fotografirani. Međutim, zbog propusta pri prikupljanju i pohrani uzoraka onemogućeno je određivanje do vrste $\mathrm{u}$ laboratoriju morfološkom razudbom i molekularnim analizama. Sukladno tome, prema morfološkim obilježjima na fotografijama ustvrdili smo kako se radi o ličinki trećeg razvojnog stadija, koja pripada porodici muha zujara (Calliphoridae), koja se spominje $\mathrm{u}$ literaturi među prvim kolonizatorima lešine (Salimi i sur., 2018.). S obzirom da analna ploča nije bila detaljno fotografirana te korišteno povećanje objekta nije bilo dovoljno za ustvrđivanje oblika trnova i režnjeva na prednjim odušcima, iz zaprimljenih fotografija se sa sigurnošću nije mogla ustvrditi vrsta. Prema drugim specifičnim morfološkim značajkama pretpostavljamo da se radilo o jedinkama vrste C. vicina. Postoji nekoliko načina kako se određuje stupanj njihova razvoja. Jedan od načina je pomoću njihove dužine, širine i težine te morfoloških obilježja specifičnih za pojedini stupanj razvoja ličinke (Harvey i sur., 2016.). Prikupljeni podatci se koriste pri izradi takozvanih izomegalnih i izomorfnih dijagrama, koji predstavljaju grafički prikaz razvoja kukaca ovisno o temperaturi. Razlika između izomegalnog i izomorfnog dijagrama je ta što se u izomegalni dijagram unosi dužina ličinke, dok izomorfni dijagram sadrži podatke o razvojnom stadiju i stupnju ličinke na temelju čega se izračunava dob. Njihovom primjenom postmortalni interval se može odrediti precizno jedino ako je temperatura gdje se lešina nalazila bila približno konstantna (npr. lešine nađene $\mathrm{u}$ zatvorenom prostoru). Kao i kod procjene PMI-a na temelju ustvrđenih postmortalnih promjena na lešini i u ovom slučaju vrijeme od prvog polaganja jajašaca smo procijenili na temelju dostupnih temperaturnih podataka i duljini najstarije jedinke muhe zujare.

$\mathrm{Na}$ razvoj većine kukaca glavni utjecaj imaju temperatura i vlaga zraka. Pojedinim vrstama za optimalan razvoj više odgovara stalna temperatura okoliša, dok nekim vrstama više odgovaraju fluktuiajuće temperature. Bitan utjecaj na njihov razvoj ima i fotoperiod, odnosno njihova izloženost svjetlu, gdje stalna dnevna svjetlost u pojedinih vrsta usporava razvoj. U literaturi se navodi kako se razvoj $C$. vicina ne odvija noću, ali istraženo je kako noću one mogu ići u potragu za hranom te vršiti ovipoziciju, ali u manjem postotku. Upravo zbog ovog razloga u procjeni postmortalnog intervala može doći do pogreške od 12 sati (Sharmaa i sur., 2015.). Posljedično tome pri procjeni postmortalnog intervala na temelju morfoloških metoda važno je detaljno dokumentirati okolišne uvjete, ponajprije klimatske. Međutim, isto tako treba uzeti u obzir i mikrostanište $\mathrm{u}$ kojem se lešina nalazi, jer takvi uvjeti ne odgovaraju ambijentalnim uvjetima. 
U prikazanom slučaju lešina se nalazila unutar pvc vrećice u prostoru napuštene štale što treba uzetiu obzir, iako smo pretpostavili kako je temperatura unutar pvc vrećice odgovarala vanjskoj temperaturi. Temperatura je mogla biti neznatno povišena, svega 2 do $5{ }^{\circ} \mathrm{C} u$ prvih 72 sata, i to zbog procesa raspadanja lešine tijekom kojih se dio topline odaje $u$ okolni prostor i zbog nalaza lešine u vreći koja je ju djelomično zadržala. C. vicina obično kolonizira lešina tijekom hladnijih vremena (Pelitero i Bordas, 2007.). Kako bi započela kolonizaciju temperatura okoliša se mora kretati oko $13{ }^{\circ} \mathrm{C}$ (Defilippo i sur., 2016.), dok je za njezin daljnji razvoj optimalna temperatura od 10-12 ${ }^{\circ} \mathrm{C}$ i $28-30{ }^{\circ} \mathrm{C}$ (Salimi i sur., 2018.). Temeljem rezultata istraživanja Donovan i sur. (2006.) kojim su ustvrđivali brzinu rasta i razvoja ličinke muhe zujare $\mathrm{s}$ obzirom na temperaturu te podatak koji iznose Vinogradova i Marchenko (1984.) i Greenberg (1991.) razvoj C. vicina nije moguć ispod $2{ }^{\circ} \mathrm{C}$. U prosjeku za 5 do 7 dana dolazi do razvoja adultnih oblika na temperaturi od $22-25{ }^{\circ} \mathrm{C}$ (Pellitero i Bordas, 2007.). Standardna tehnika korištena za procjenu stope razvoja kukaca tijekom vremenskog razdoblja $\mathrm{s}$ kompenzacijom temperature naziva se akumulirani stupanj sati (ADH) ili akumulirani stupanj dana (ADD), koji predstavljaju zbroj temperature $\left({ }^{\circ} \mathrm{C}\right)$ iznad nižeg razvoja praga (LDT) pomnožen s vremenom (sati ili dani). LDT je temperatura ispod koje se zaustavlja razvoj kukaca, najčešće se procjenjuje mjerenjem stopa razvoja na rasponu temperatura i uklapanju regresijske linije na rezultate (Defilippo i sur., 2007.). Kako bi se dobili vjerodostojni rezultati računanjem $\mathrm{ADH}$ ili $\mathrm{ADD}$ okolišna temperatura mora se kretati u rasponima sličnim onima koji se navode kao referentni za razvoj pojedinog stadija (Sharmaa i sur., 2015.). Prema Donovanu i sur. (2006.) za dostizanje trećeg stadija dužine od $15 \mathrm{~mm}$ potrebno je od 1200 do 2400 akumuliranog stupnja sata-

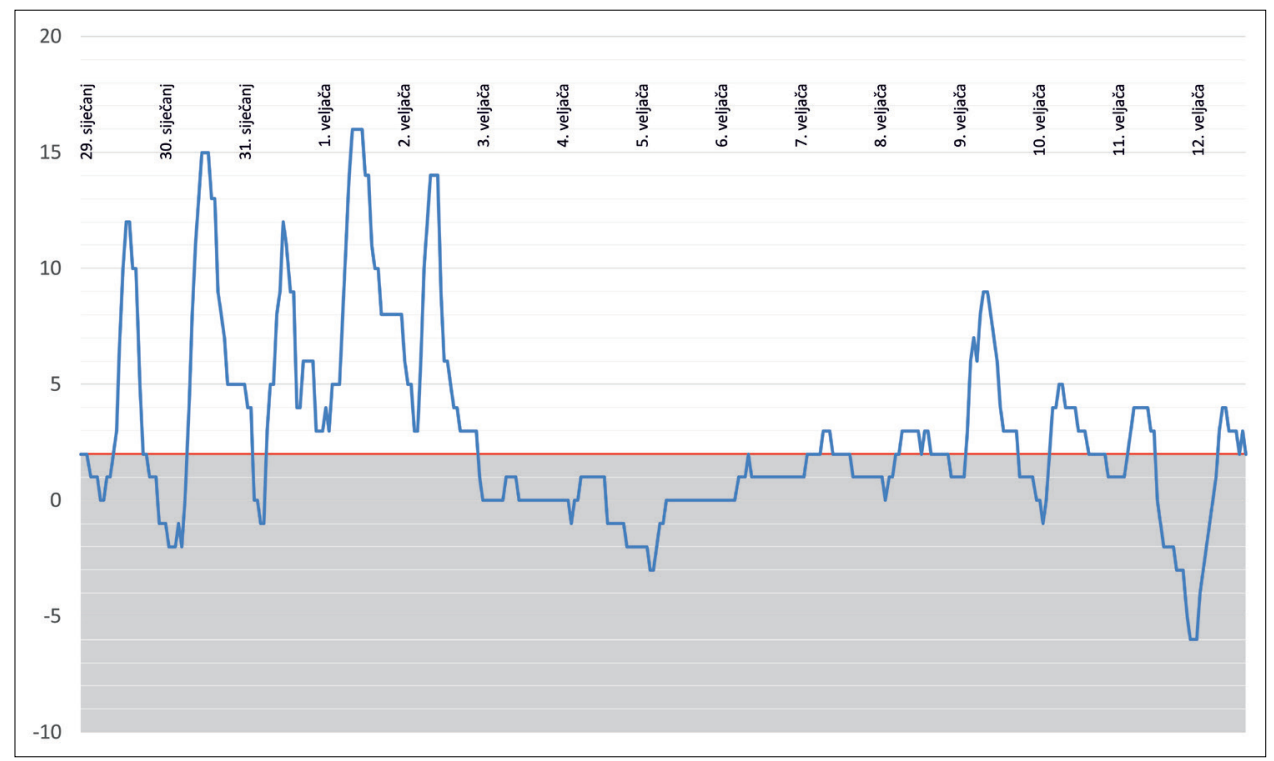

Slika 6. Grafički prikaz dnevnih kretanja temperature zraka s područja najbliže mjerne postaje od 29 siječnja do 12. veljače. Horizontalnom crvenom linijom označena je granična temperatura od $2^{\circ} \mathrm{C}$ ispod koje nije moguć razvoj ličinka C. vicina. 
zbroj temperatura svakog sata tijekom razvoja te da pri stalnoj temperaturi od $4{ }^{\circ} \mathrm{C}$ ličinka postiže navedenu dužinu i stupanj razvoja za 620 sati. Kako je razvoj vrste C. vicina zabilježen do svega $2{ }^{\circ} \mathrm{C}$ stupnja, uzimajući u obzir temperaturna kretanja izračunali smo kako se dostatan akumulirani stupanj dana mogao stvoriti ukoliko je lešina bila stara najmanje 14 dana, odnosno da smrt nikako nije mogla nastupiti prije 29. siječnja (Slika 6.).

Dakako, prethodni zaključci vrijede ako lešina nije mijenjala mjesto na kojem je pronađena, odnosno ako su temperaturna kretanja $u$ napuštenoj štali i mikrocirkulacija odgovarala kretanjima s područja mjerne postaje gdje je lešina pronađena. Uz okolišne faktore postoje i brojni drugi faktori koji utječu na brzinu razvoja pojedinih insekata kao što su: toplina nastala procesima truljenja, uslijed masovne kolonizacije kukaca, dostupnost hrane, način njihova sakupljanja i mjerenja te se posebno ističu različite vrste droga i lijekova unesene prehranjivanjem na lešini (Harvey i sur., 2016.). Bitno je naglasiti kako i masovna invazija kukaca i njihovih razvojnih stadija može stvoriti veliku razliku između temperature lešine i okoliša te se razlika može kretati od 1 do $3{ }^{\circ} \mathrm{C}$ što dovodi do ubrzanja njihova životnog ciklusa (Sharmaa i sur., 2015.).

Određivanje postmortalnog intervala izrazito je kompleksan proces te prilikom njegove procjene treba prikupiti što je moguće više podataka. Kao što je vidljivo iz prikazanog slučaja postmortalne promjene ne mogu dati precizan uvid u vrijeme koje je proteklo od smrti jedinke, jer je jako puno faktora koji utječu na njih. $S$ druge strane, entomološki nalaz može dati precizniji uvid u PMI i to posebice kada se radi o lešinama starijim od 72 sata.

\section{Literatura}

1. ANDERSON, G. S. (2013): Forensic Entomology: The use of Insects in Animal Cruelty Cases. In:
Merck, M. D.: Veterinary Forensics: Animal Cruelty Investigations, Second Edition, John Wiley \& Sons, USA (273-286).

2. AYDIN, B., B. COLAK, Y. BALAI and C. DEMIRUSTU (2010): Consistency of postmortem interval estimations of physicians using only postmortem changes of putrefied dead bodies. Am. J. Forensic Med. Pathol. 31, 243-246.

3. BROOKS, J. W. (2016): Postmortem changes in animal carcasses and estimation of the postmortem interval. Vet. Pathol. 53, 929-940.

4. BROWN, K., A. THORNE and M. HARVEY (2015): Calliphora vicina (Diptera: Calliphoridae) pupae: a timeline of external morphological development and a new age and PMI estimation tool. Int. J. Legal Med. 129, 835-850.

5. BRUNDAGE, A. and J. H. BYRD (2016): Forensic entomology in animal cruelty cases. Vet. Pathol. 53, 898-909.

6. BYRD, J. H. and J. K. TOMBERLIN (2009): Laboratory Rearing of Forensic Insects. In: Byrd, J. H.: Forensic Entomology: The Utility of Arthropods in Legal Investigations CRC Press, Boca Raton, FL (705).

7. DEFILIPPO, F., S. RUBINI, M. DOTTORI and P. BONILAURI (2016): The use of forensic entomology in legal veterinary medicine: A case study in the North of Italy. J. Forensic Sci. Criminol 4, 101.

8. DONOVAN, S. E., M. J. HALL, B. D. TURNER and C. B. MONCRIEFF (2006): Larval growth rates of the blowfly Calliphora vicina, over a range of temperatures. Med. Vet. Entomol. 20, 106-114.

9. DŽAJA, P. i Ž. GRABAREVIĆ (2011): Sudsko veterinarstvo-opći dio. Tiskara Zelina d.d., Zagreb (11-41).

10. ERLANDSSON, M. and R. MUNRO (2007): Estimation of the post-mortem interval in beagle dogs. Sci. Justice 47, 150-154.

11. GRABAREVIĆ, Ž. i R. SABOČANEC (2016): Osnove razudbe domaćih životinja. Medicinska naklada, Zagreb (35-52).

12. GREENBERG, B. (1991): Flies as Forensic Indicators. J. Med. Entomol. 28, 565-577.

13. HARVEY, L. M., N. E. GASZ and S. C. VOSS (2016): Entomology-based methods for estimation of postmortem interval. Res. Rep. Forensic Med. Sci. 6, 1-9.

14. JOSEPH, I., D. G. MATHEW, P. SATHYAN and G. VARGHEESE (2011): The use of insects in forensic investigations: An overview on the scope on forensic entomology. J. Forensic Dent. Sci 3, 89-91.

15. MARTIN-VEGA, D. and M. J. R. HALL (2016): Estimating the age of Calliphora vicina eggs (Diptera: Calliphoridae): determination of embryonic morphological landmarks and preservation of egg samples. Int. J. Legal Med. 130, 845-854.

16. MERCK, M. D. and D. M. MILLER (2013): Postmortem Changes and The Postmortem Interval. In: Merck, M. D.: Veterinary Forensics: Animal Cruelty Investigations, Second Edition, John Wiley \& Sons, USA (255-271). 
17. MOORE, H. and S. SHEMILT (2017): Cuticular Hydrocarbon Analysis in Forensic Entomology: A Review. AEFS 1.2, (127-138).

18. MUNRO, R. and H. M. C. MUNRO (2008): Estimation of Time since Death In Animal abuse and unlawful killing, Forensic veterinary pathology, Elsevier Ltd., UK (88-93).

19. PELLITERO, J. M. and M. I. S. BORDAS (2007): Development of Calliphora Vicina RobineauDesvodiy (Diptera, Calliphoridae) under starvation conditions. Boletín Sociedad Entomológica Aragonesa 41, 413-417.

20. PROCTOR, K. W., W. J. KELCH and J. C. NEW (2009): Estimating the time of death in domestic Canines. J. Forensic Sci. 54, 1433-1437.

21. SALIMI, M., Y. RASSI, M. OSHAGHI, O. CHATRABGOUN, M. LIMOEE and S. RAFIZADEH
(2018): Temperature requirements for the growth of immature stages of blowflies species, Chrysomya albiceps and Calliphora vicina, (Diptera: Calliphoridae) under laboratory Conditions. Egypt. J. Forensic Sci. 8:28.

22. SHARMAA, R., R. K. GARG and J. R. GAUR (2015): Various methods for the estimation of the post mortem interval from Calliphoridae: A review. Egypt. J. Forensic Sci. 5, 1-12.

23. ŠKAVIĆ, J. (2004): Tanatologija. U: Zečević, D. i sur.: Sudska medicina i deontologija. Medicinska naklada, Zagreb (29-41).

24. VINOGRADOVA, E. B. and M. I. MARCHENKO (1984): Use of Temperature Parameters of the Development of Flies in Forensic Medical Practice. Sud. Med. Ekspert 27, 16-19.

\section{Assessment of post-mortem interval based on post-mortem changes and entomological findings}

Magdalena PALIĆ, DVM, Assistant, Petar DŽAJA, DVM, PhD, Full Professor, Andrea GUDAN KURILJ, DVM, PhD, Associate Professor, Krešimir SEVERIN, DVM, PhD, Full Professor, Faculty of Veterinary Medicine University of Zagreb, Croatia; Lucija ŠERIĆ JELASKA, $\mathrm{PhD}$, Expert Associate, Senior Scientific Associate, Department for Biology, Faculty of Science, University of Zagreb, Croatia

The post-mortem interval (PMI) is the time elapsed since the death of an animal. The assessment of PMI leads us to determine the manner and circumstances of death, and in some cases, aids in finding the offender. This article presents a case of a suspected crime of killing and torturing animals, and apart from the cause of death, it was necessary to determine the post-mortem interval. The determination of PMI was based on the assessment of postmortem changes and entomological findings. After death, the animal body undergoes certain changes resulting from the cessation of vital functions and cell death. These changes are irreversible and progressive, leading ultimately to complete decomposition of the body. During the investigation, signs of putrefaction and the absence of postmortem muscle rigidity were advanced, and it was impossible to precisely establish
PMI based solely on postmortem changes. In cases where post-mortem insect colonization is present, it is possible to establish PMI by determining insect type and development stage, and the influence of environmental factors on their development. According to the available entomological evidence and observed morphological characteristics, the larvae were classified to belong to the fly family (Calliphoridae), and determination was made to the species Calliphora vicina with a given level of certainty. Namely, due to the inability to collect and store samples, it was not possible to establish the exact species determination based on morphological and molecular analyses. Nevertheless, this finding contributed significantly to PMI assessment and helped to solve the case.

Key words: post-mortem interval; forensic entomology; post-mortem changes 